\title{
On the Identity and Uses of Cantonese Sentence-final Particles in the Late 20th Century: The Case of wo (喎) and bo (噃)
}

\author{
Wai-Mun Leung \\ Department of Chinese, The Hong Kong Institute of Education \\ 10 Lo Ping Road, Taipo, Hong Kong \\ Tel: 852-2948-7223Ｅ-mail: waimun@ied.edu.hk
}

\begin{abstract}
This paper mainly describes the uses of the frequently used sentence final particles wo3 and bo3 in the 1990 s in Hong Kong Cantonese by examining speech data. In the past twenty years, most experts treated wo3 and bo3 as variant forms, the former being the result of sound change from the latter (Kwok 1984, Luke 1990, Li 1995, Fang 2003). In order to verify whether wo3 and bo3 are different particles or free variations of the same particle, the synchronic picture of the two particles will be considered by comparing their uses and functions in the 1990s with the language examples from the Hong Kong University Cantonese Corpus and local movies.
\end{abstract}

Keywords: Cantonese, Sentence-final Particles, Late 20th Century, Spoken data, Synchrony

\section{Introduction}

\subsection{Cantonese sentence-final particles}

Sentence final particles (hereafter SFPs) in Cantonese play an important role in determining the function of sentence. They are scarcely found in formal writing but their presence in common conversation is massive. SFPs function to convey speech act information and often have grammatical functions, such as changing a declarative sentence into an interrogative one.

Most researchers (Cheung 1972, Kwok 1984, Ouyang 1990, Luke 1990, Deng 1991, Matthews \& Yip 1994, Li 1995, Fang 2003, Leung 2005, Cheung 2007) have come to consider that SFPs as mainly conveying the speaker's emotions and attitudes, and that they are found in casual conversations only. Some sources on Cantonese have identified thirty or more basic forms (Kwok 1984) and over forty-five possible particle clusters (Leung 2005). Cheung (2007:183-208) pointed out that there are as many as seventeen particles commonly found in everyday conversation, which are often used in clusters of two to four, namely lo1, bo3, aa3, wo2, tim 1, gwa3, me1, ze1, maa3, ne1, ge2, lai4, sin1, zyu6, faat1, baa2laal and hai2laa1.

\subsection{Research motivation}

Among the basic SFPs that are used in everyday conversation, wo3 (喎, mid level tone) is certainly the one with high frequency. In terms of frequency of usage of wo3 and bo3, there is an imbalance between them as wo3 has entirely surpassed the using of bo3 (噃, mid level tone) in today’s Hong Kong Cantonese. According to the Hong Kong University Cantonese Corpus (HKUCC, see 1.3), the appearance of the two is 602 to 16 in ratio, wo3 is about 38 times as frequently used as bo3 in contemporary Cantonese. However, teaching materials and academic books have only occasionally mentioned wo3 and the explanations are often too short. If wo3 is not seen as "the same as bo3", it is being thought of as the variant or weakened form of bo3. Then the major effort is put on explaining the function, usage and meaning of bo3. Undeniably, among these archives, we get an impression that the two SFPs wo3 and bo3 have very close relationship; in other words, they are described to be the same essentially.

Luke (1990) is the one who firstly realized that wo3 has already changed to become an SFP with high frequency of daily use and through frequent use has gained itself an independent position different from bo3. His work has an entire chapter devoted to the detailed discussion of wo3. He has concluded the meaning of wo3 as "unexpectedness, noteworthiness, remarkableness, unusualness...etc”. After Luke has noted the new status of wo3, there have been scholars noticing and discussing this SFP continuously over the past decades (Ouyang 1990, Matthews \& Yip 1994, 
Leung 2005). They point out that the meaning of wo3 is "reminding, discussing and enlightening", which is very similar to the definition of bo3 in the earlier works (Ball 1888, O'Melia 1954, Cheung 1972). This suggests the current SFP wo3 could have been derived from bo3. Table 1 concisely summarizes scholars' views on the usage of and the tones expressed by bo3 and wo3 from 1888 to 2007. Unlike the particle bo3, it can be seen that there was little mention of wo3 among them before the 1990s. With this background, it seems reasonable to proceed one step further to present a synchronic analysis by examining the data of colloquial speech in detail to verify the differences between $b o 3$ and wo 3 in Hong Kong Cantonese in the late 20th century, and this is the goal of this paper.

The "Cantonese" in the following discussions is the variety spoken in Hong Kong and the Jyutping Romanization scheme (瞚拼, Linguistic Society of Hong Kong 1993) is adopted for the notations of Cantonese sounds.

\subsection{Data collection}

It is noted that the best source of information for linguistic features is a large corpus of colloquial speech for us to perform statistical analyses. Since a speech corpus is constructed using real data and so is highly representative, our analysis will no longer be based on a small sample or subjective feelings. The Hong Kong University Cantonese Corpus (HKUCC) was set up out of such objective. The language examples for the 1990s in this paper fundamentally come from the HKUCC, and are supplemented with two popular Cantonese movies produced in the 1990s, namely "Fight back to the school I" (Fight 1991) and "Fight back to the school II" (Fight 1992). The movies starred Stephen Chow S. C., one of the best known actors then in Hong Kong. Below is a brief background of the HKUCC.

In the 1990s the University of Hong Kong established a corpus made up of a large amount of Cantonese speech and conversational recordings which have been fully transcribed, segmented, tagged and parsed. HKUCC was built up on the basis of a research project entitled "Constructing a Database of Spoken Cantonese with English Translation and On-line Dictionary”, funded by the Hong Kong Research Grants Council (HKU 397/96H). These speech data are all genuine, colloquial, unscripted, spontaneous speech as heard in everyday conversations. In the 150 recordings of this 200,000 word corpus, 67 were conversations between 2-3 speakers, 51 were radio broadcasts and 32 were stories told by one story-teller. It is also equipped with quick and convenient searching and retrieving tools.

By systematically recording a substantial amount of speech, the HKUCC provides researchers with a convenient and reliable way of checking and substantiating speakers' feelings and intuitions about their language. Take frequency information as an example, if it were not with the HKUCC, one would not be able to quantify the relative degree of use of the SFPs $b o 3$ and wo3. A quick check of the corpus reveals that the use of these two particles is in a ratio of 16:602; wo 3 is about 38 times as frequently used as bo3 in contemporary Cantonese. Of the entire corpus mentioned above, this research focuses on 8 hours of data.

\section{The uses of wo3 in the late 20th century}

In modern Cantonese, wo3 is an SFP used with a high frequency. Some recent researches have shown that this particle is used to show "realization and reminders" (Rao 1983, Kwok 1984, Ouyang 1990, Deng 1991, Leung 1992, Fang 2003). Wo3 can be commonly used at the end of declarative and exclamatory sentences. Consider some common examples:

Example 1 (Fight 1992)

$\begin{array}{lllll}\text { 今日 } & \text { 天氣 } & \text { 好 } & \text { 好 } & \text { 喎 } \\ \text { gam1jat6 } & \text { tin1hei3 } & \text { hou2 } & \text { hou2 } & \text { wo3 } \\ \text { today } & \text { weather } & \text { very } & \text { good } & \text { SFP }\end{array}$

"The weather is very good today!"

Example 2 (Fight 1991)

$\begin{array}{lllll}\text { 呢度 } & \text { 唔 } & \text { 准 } & \text { 食煙 } & \text { 喎 } \\ \text { lei1dou6 } & \mathrm{m} 4 & \text { zeon2 } & \text { sik6 jin1 } & \text { wo3 } \\ \text { here } & \text { NEG } & \text { allow } & \text { smoking } & \text { SFP }\end{array}$

"Smoking is not allowed here!" 
Example 3 (HKUCC)

$\begin{array}{lllcc}\text { 嘩! } & \text { 真係 } & \text { 幾 } & \text { 梳夫 } & \text { 喎! } \\ \text { Waa3 } & \text { zan1hai6 } & \text { gei2 } & \text { solfu1 } & \text { wo3 } \\ \text { INJ } & \text { really } & \text { quite } & \text { wonderful } & \text { SFP }\end{array}$

"Wow, it's quite wonderful!"

Example 1 is a declarative. Wo3 in this sentence expresses mirativity (DeLancey 1997, Matthews 1998a). The speaker expresses surprise or wonder at the unusually or unexpectedly pleasant weather. Example 2 is a reminder "you should know smoking is not allowed here". Example 3 is an exclamatory sentence. The particle wo 3 can be used in different types of sentences expressing various tones of voice in conjunction with different lexical and intonational devices. In the HKUCC, the SFP aa3 (啊), found to be the most frequently occurring, is used more than 2000 times. However, the expressive function of $a a 3$ is not as specific as that of wo3 since its major function is to soften the tone of a statement (Leung 2008).

According to our observations of the HKUCC data, in present-day Cantonese, the SFP wo3 is primarily used to convey the meanings of: (1) Realization, (2) Reminder, (3) Hearsay and (4) Contrast. Two examples of each are shown below with explanations.

\subsection{Realization}

In Example 4, Speaker A reminds Speaker B that it is nearly three o'clock and as a result Speaker B remembers that there is a scheduled gathering so she may need to do some preparations. In Example 5, the speaker takes some bones to feed a dog, and then remembers that in the backyard there is also a cat, which might be hungry then, and so he takes some food to feed the cat too. Unlike the reminder, the one who "realizes" that something has to be done is the speaker himself.

Example 4

$$
\begin{aligned}
& \mathrm{A}: \text { 三 點 䇏 } \\
& \text { saam1 } \operatorname{dim} 2 \text { laa3 } \\
& \text { three o'clock SFP } \\
& \text { "It's three o'clock already." } \\
& \begin{array}{cccc}
\text { B : 係 } & \text { 喎, 佢 哋 會 } & \text { 敬 } & \text { 縏 } \\
\text { hai6 } & \text { wo3, keoi5dei6 wui5 } & \text { lai4 } & \text { laa3 } \\
\text { yes } & \text { SFP, they AUX } & \text { come } & \text { SFP }
\end{array}
\end{aligned}
$$

"Oh yes. They are coming soon."

Example 5

拎 啲 骨頭去 餵 吓狗先, 橫掂無 嘢

ling1 di1 gwat1tau4 heoi3 wai3 haa5 gau2 sin1, waang4dim 1 mou4 je5

Take CL bone go feed ADV dog first, anyway no thing

做...... 係喎, 後面重有隻貓, 唔 知 餓

zou6......hai6 wo3, hau6min6 zung6 jau5 zek3 maau1, m4 zi1 ngo6

do... yes SFP, back still have CL cat, NEG know hungry

唔 餓呢?

$\mathrm{m} 4$ ngo6 ne1?

NEG hungry SFP

"Let me take the bones and feed the dog as I have nothing to do now... Oh, there's also a cat in the backyard, is it hungry or not?" 


\subsection{Reminder}

"Reminding" and the above-mentioned "Realization" are two sides of the same coin. In "reminding", it is the speaker who reminds the hearer and consequently the hearer remembers something, while in "realization", the speaker suddenly realizes something as a result of the reminder by someone or some situations, and in this case it is the speaker who remembers something. Each of the two examples below shows a situation where the hearer remembers something as a result of the reminder of the speaker. In Example 6, Speakers A and B are discussing Chinese tea and milk tea. Prior to this exchange, Speaker B said that milk tea certainly does no harm to his stomach and he always drinks Chinese tea. But Speaker A reminds B that Chinese tea is mild, which is different from milk tea. In Example 7, someone asks the speaker to help return some books to the library, but the speaker refuses and gives the reason that he is too busy, and he also reminds the hearer that returning books to the library is very simple as one needs only to place the books in the bookdrop.

\section{Example 6 (HKUCC)}

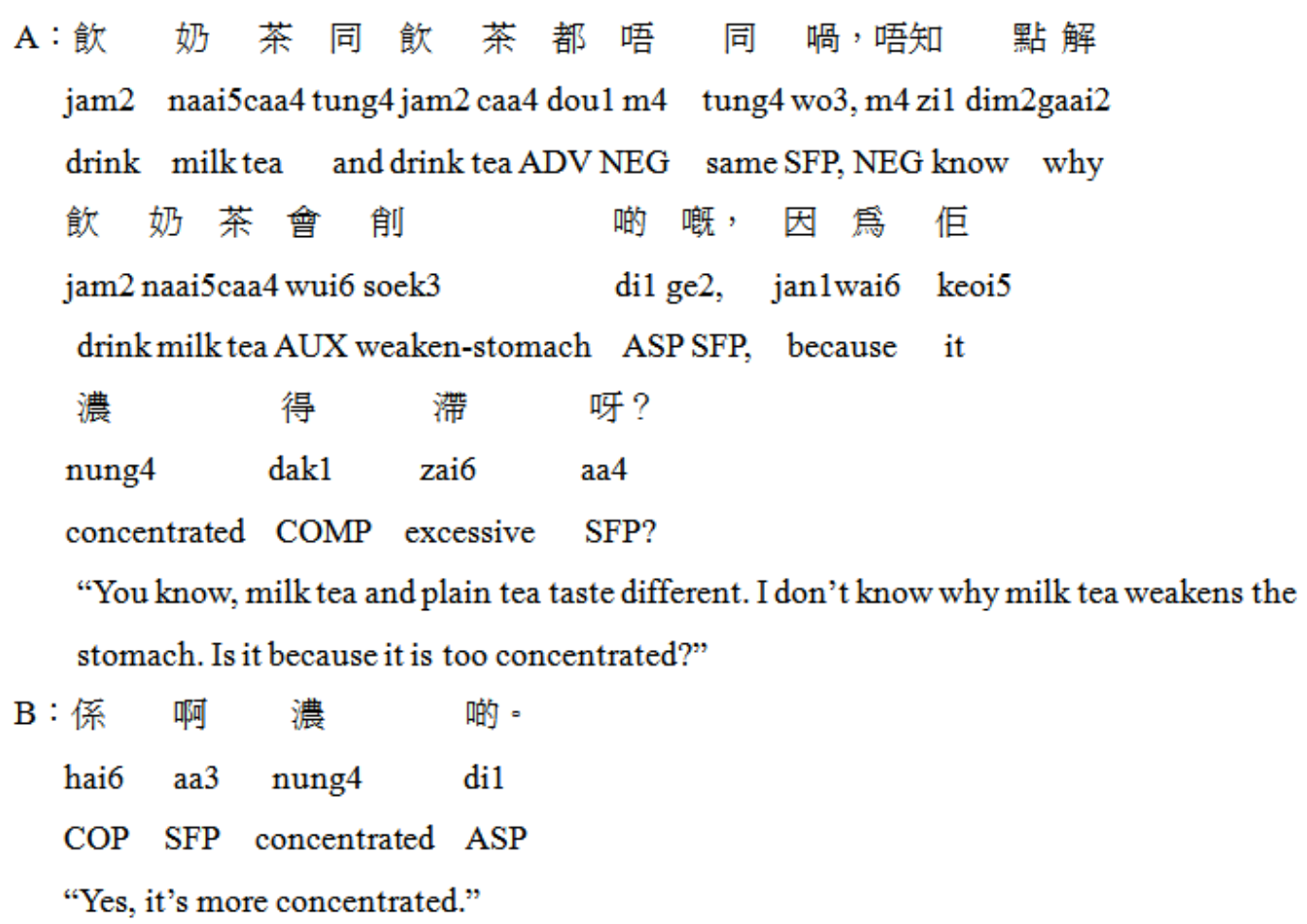

Example 7 (HKUCC)

你千新唔好搵我啊, 我已經九個 project 啊,

nei5 cin 1 kei $4 \mathrm{~m} 4$ hou2 wan2 ngo5 aa3, ngo5 ji5ging1 gau2 go3 project aa3,

1SGADV NEG good find 1SG SFP, 1SG already nine CL project SFP,

你自己去還 啦, 你自己隊埋去喎

nei5 zi6gei2 heoi3 waan4 laa1, nei5 zi6gei2 deoi6 maai4 heoi3 wo3

2SG self go return SFP, 2SG self hand in ASP go SFP

"Don't ask me to do it as I have nine projects at hand already. Why don't you go yourself? You

just need to drop it."

\subsection{Hearsay}

The third category is "hearsay", that is reporting other people's speech. Back at the end of the 19th century, the function of wo was already identified as "denoting that the statement preceding it has been made by some one before" (Ball 1888). In modern Cantonese, there are two particles which express hearsay function, namely wo3 and wo5. In many situations, these two particles are interchangeable, but there are subtle differences between the two (Leung 2009). In Example 8, the speaker conveys good wishes to the hearer from someone else who is not present. In Example 9, wo3 also has a hearsay function, as the speaker asks the other party who plays most wildly and the hearer answers that he 
plays most wildly. The particle wo3 at the end of the sentence expresses the fact that this assessment is from someone else other than the speaker.

Example 8 (Fight 1991)

佢 話 問候 你 喎, 王 Sir!

keoi5 waa6 man6hau6 nei5 wo3, wong2 sir

$3 \mathrm{SG}$ say greet 2SG SFP, Wong Sir!

"He has asked me to send his regards to you, Mr. Wong!"

Example 9 (HKUCC)

我問阿甲呢, 邊個玩得最癲呢,

ngo5 man6 aa3gaap3 ne1, bin1go3 waan2 dak1 zeoi3 din1 ne1,

1SG ask PRE-A SFP, who play COM most wildly SFP,

佢話佢喎。

keoi5 waa6 keoi5 wo3

3SG said $3 \mathrm{SG} \quad \mathrm{SFP}$.

"I asked him who played the most wildly, and he said he did."

\subsection{Contrast}

The fourth category is "show an element of Contrast". In Example 10, Speaker A hears some noises in the car park and feels worried, as there are valuables in the car. He then asks Speaker B whether everything is fine. Speaker B replies that, contrary to A's worries, there is no problem with the car. In Speaker B's reply, wo3 appears at the end of the utterance and conveys the meaning "in spite of appearances or what you think, the car is okay". Thus, the particle shows that the message contains an element of "contrast". Similarly, in Example 11, Speaker A says that there is no one in the room, but Speaker B discovers that the grandmother is in the room and reminds Speaker A that the actual situation is different from the one he described, despite the fact that Speaker A implies that whether the grandmother is present or not will not affect them in any way. The wo3 at the end of Speaker B's utterance again carries an element of "contrast".

Example 10 (Fight 1991)

$$
\begin{aligned}
& \text { A : 有 有 嘢 啊? } \\
& \text { jau5 mou5 je5 aa3 } \\
& \text { have NEG thing SFP? } \\
& \text { "Is there something wrong?" } \\
& \text { B : 架 車 右 嘢 喎 = } \\
& \text { gaa3 ce1 mou5 je5 wo3 } \\
& \text { CL car NEG thing SFP }
\end{aligned}
$$

"Contrary to what you think, there's nothing wrong with the car."
A : 噉 點解 曾 有 聲 嘅?
gam2 dim2gaai2 wui5 jau5 seng1 ge2
DM why AUX have sound SFP?

"Then why are there some noises?"

$\begin{array}{ccc}\text { B : 周圍 } & \text { 睇 } & \text { 吓。 } \\ \text { zau1wai4 } & \text { tai2 } & \text { haa5 } \\ \text { Around } & \text { look } & \text { ASP }\end{array}$


Example 11 (Fight 1992)

$$
\begin{array}{clcl}
\text { A : 房 } & \text { 入面 } & \text { 布 } & \text { 人 } \\
\text { fong2 } & \text { jap6min6 } & \text { mou5 } & \text { jan4 } \\
\text { room } & \text { inside } & \text { no } & \text { person }
\end{array}
$$

"There's nobody in the room."

$$
\begin{array}{cccc}
\text { B : 阿嫲 } & \text { 係 } & \text { 度 } & \text { 喎 } \\
\text { aa3maa4 hai2 } & \text { dou6 } & \text { wo3 } \\
\text { PRE-grandmother } & \text { COP } & \text { here } & \text { SFP } \\
\text { "Hey but Granny is here." } &
\end{array}
$$

$\begin{array}{cllll}\text { A : 唔 } & \text { 使 } & \text { 理 } & \text { 佢 } & \text { 㗎 } \\ \text { m4 } & \text { sai2 } & \text { lei5 } & \text { keoi5 } & \text { gaa3 } \\ \text { NEG } & \text { need } & \text { care about } & \text { 3SG } & \text { SFP }\end{array}$

"No need to care about her."

\subsection{Novel usage}

It is worth mentioning that wo3 can also appear at the end of imperative and exclamatory utterances to carry a sense of emphasis. It should be noted that the use of the sentence final particle wo3 with imperative and exclamatory utterances is possibly new; as such usage is not found in the data of the early 20th century (Wisner 1906, Ball 1924, Sung 1934). Example 12 is a dialogue between a leader and his attendant. "Follow me closely" is an order to be followed strictly. The imperative tone-of-voice is not expressed by the particle wo3. If wo3 is replaced by another particle such as aa3, the tone-of-voice of the utterance is not changed, but the particle wo3 gives the hearer a strong sense of "reminder". In Example 13, the speaker is at a friend's home and expresses his exclamation as he is watching the beautiful sea view from the living room. Wo3 serves as a reminder to the friend and intensifies the exclamation. This use of wo3 with imperative and exclamatory utterances seems to be a novel one. Moreover, the category mirative in this example indicates unexpected information (such a fantastic view) which the speaker does not anticipate.

\section{Imperative}

Example 12 (Fight 1991)

$\begin{array}{lcccccc}\text { 一陣 } & \text { 你 } & \text { 要 } & \text { 跟 } & \text { 實 } & \text { 我 } & \text { 喎, } \\ \text { jat1zan6 } & \text { nei5 } & \text { jiu3 } & \text { gan1 } & \text { sat6 } & \text { ngo5 } & \text { wo3 } \\ \text { later } & \text { 2SG } & \text { must } & \text { follow closely } & \text { 1SG } & \text { SFP } \\ \text { 咪 } & \text { 又 } & \text { 再 } & \text { 闖禍 } & \text { 啊 } & \\ \text { mai2 } & \text { jau6 } & \text { zoi3 } & \text { cong2wo6 } & \text { aa1 } & \\ \text { NEG } & \text { again } & \text { again } & \text { make trouble } & \text { SFP } & \end{array}$

"Remember, follow me closely and don't make trouble again."

\section{Mirative}

Example 13 (Fight 1991)

嘩, 個 景 好 靚 喎!

waa 3 , go 3 ging 2 hou 2 leng 3 wo 3

INJ, DEM view INT pretty SFP

"Wow, the view is very beautiful!" 


\subsection{Short summary}

We saw in this section from our observations of the spoken data, in the 1990s, the particle wo3 was mainly used to convey the moods of: (1) Realization, (2) Reminder, (3) Hearsay and (4) Contrast. It is also used with imperative or exclamatory utterances, in which the tone-of-voice is not expressed by wo3 but by the imperative or exclamatory utterances themselves. This usage of wo3 is hardly found in the past corpus data; it is a novel usage and serves to indicate the fact that the functions of the particle wo3 are still evolving. In the next sections, the uses of bo3 in the late $20^{\text {th }}$ century will be discussed and compared with those of wo3.

\section{The uses of bo3 in the late 20th century}

In the HKUCC, the SFP bo3 occurs very rarely as an independent SFP. Only five cases were found. Out of the five cases, four are used in short negative sentences while only one case is positive. It is clear that the mood conveyed by this particle is to show "contrast". The following are the five examples of bo3 used singly found in the HKUCC. It is used with short negative sentences in four examples to indicate "contrary to the listener's expectations" (see 3.1), and is used in one single example conveying "realization" (see 3.2).

\subsection{Contrast}

The SFP bo3 in the first four examples below is used with short negative utterances to show "contrast":

Example 14 (HKUCC)

$\begin{array}{rlllll}\text { A : 你 fang4 } & \text { 機, 我 開 } & \text { 大 } & \text { 啲 } \\ \text { nei5 } & \text { fang4 } & \text { gei1, ngo5 hoi1 } & \text { daai6 } & \text { di1 } \\ \text { 2SG play machine, 1SG turn on } & \text { loud } & \text { ASP }\end{array}$

"A: You want to play the Hi-Fi, I turn it louder."

B : 唔係 噃, 但係 你 fang4 機, 佢 可以搵 差人 喎 $\mathrm{m} 4$ hai6 bo3, daan6hai6 nei5 fang4 gei1, keoi5 ho2ji5 wan2 caai1jan4 wo3

NEG COP SFP, but 2SG play machine, 3SGAUX find police SFP

"No, but if you play it too loud, s/he can call the police".

This dialogue happened late at night. Speaker A said that it was possible to increase the volume of the Hi-Fi, but Speaker B immediately reminded him, contrary to his expectation, that if the volume was too high, his neighbour could complain about it to the police. In Speaker B's utterance, bo3 shows "contrast", and wo3 at the end of the last utterance "s/he can call the police" has a reminding function, bringing the hearer's attention to the situation which the hearer should have knowledge of, but is not currently thinking about. Therefore, the functions of these two particles are different.

Example 15 (HKUCC)

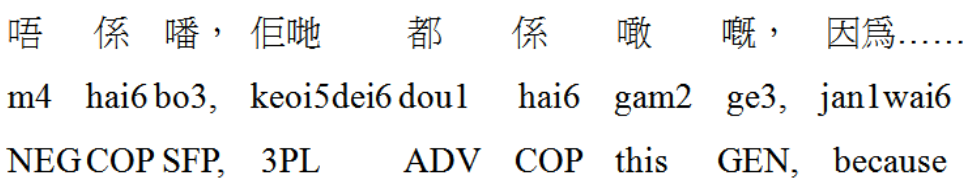

"No, (contrary to what you think) they also did so because....."

In the above example, the hearer dislikes the way some people have acted and believes other people may not act this way. The speaker immediately explains to him that the situation is actually the same, and that there must be a reason why the people acted that way, and then he provides the reason to the hearer. The SFP bo3 functions to show contrast, that is, to show the thing which is different from what the hearer thinks.

The two examples below also reveal the crucial function of bo3 is to show that something is contrary to the hearer's expectations. In Example 16, the speaker means he does not have the knowledge or control of the matter that the hearer asked, and he asks the hearer to seek the answer from the persons who are responsible for the matter. In Example 17, Speaker A asks Speaker B whether C has ever gone out. The particle bo3 in Speaker B's reply "No" carries a sense of "contrast" meaning despite of A's doubt, C keeps staying in the room. 
Example 16 (HKUCC)

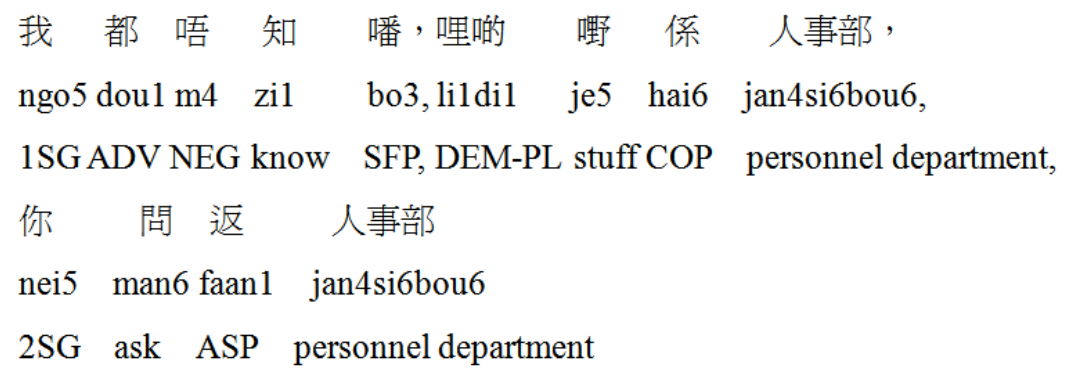

"I don't know either. This is the business of human resource department, you should ask them."

Example 17 (Fight 1991)

$\begin{array}{ccccccc}\text { A : 哦, 噉 } & \text { 有 } & \text { 布 } & \text { 出 過 } & \text { 嚟 } & \text { 啊? } \\ \text { o2, gam2 } & \text { jau5 } & \text { mou5 } & \text { ceot1 gwo3 } & \text { lai4 } & \text { aa3 } \\ \text { INJ, DM } & \text { have } & \text { NEG } & \text { out } & \text { ASP } & \text { come } & \text { SFP? }\end{array}$

"Oh, then has he gone outside?

$\mathrm{B}$ : 布噃

mou 5 bo 3

NEG SFP

"No."

\subsection{An exceptional case}

Out of the five cases of the single bo3 found in the spoken data, only the following example is an exceptional case which appears in the positive sentence and conveys the mood of "realization":

Example 18 (HKUCC)

$$
\begin{aligned}
& \mathrm{A} \text { : 係啊, 四代同堂叫嘛我哋。 } \\
& \text { hai6 aa3, sei3 doi6 tung4 tong4 aa1 maa3 ngo5dei6 }
\end{aligned}
$$

COP SFP, four generation same house SFP SFP 1PL

"Yes, we are four generations in a house."

$$
\begin{gathered}
\text { B : 真係 犀利, 果然 係 大 家族 噃 } \\
\text { zan1hai6 sai1lei6, gwo2jin4 hai6 } \\
\text { Really COP great, ADV gaa1zuk6 bo3 } \\
\text { "Wow! You really have a big family!" }
\end{gathered}
$$

In the above example, the particle bo3 can be substituted by wo3 in modern Cantonese, not only with no change in meaning but also with more naturalness. Speaker A tells Speaker B that his parents, grandparents and great grandparents are alive and well, and so four generations are present together, which is regarded as a blessing in the eyes of the Chinese. Speaker B agrees with Speaker A that Speaker A does have a big family, showing his realization of something that he did not know before, and the particle $b o 3$ in this example functions to show "realization", different from the four examples above. "Realization" was once the old usage of bo3 (table 1) and is infrequently used to show "realization" nowadays. It is the basic function of modern Cantonese particle wo3 (see 2.1). Since in the HKUCC there is only one example of such use, we lack evidence to prove that such usage is the function of the particle bo3. It would be better to treat this function as a residue of the old usage of bo3. Moreover, in Hong Kong Cantonese the particle bo3 can normally be used together with gaa3 (and its variant go3), laa3 (and its variant lo3), timl and zaa3 to form the two-particle clusters gaa3bo3, laa3bo3, timbo3 and zaa3bo3, and three-particle clusters gaa3laa3bo3 and gaa3zaa3bo3. 


\subsection{Short summary}

The data show that in modern Cantonese, the fundamental function of the SFP bo3 is to show contrast in the short negative sentences. It is less often used singly and appears very rarely as an independent SFP. Bo3 tends to be used mainly with other particles to form particle-clusters, such as gaa3bo3, tim1bo3, zaa3bo3 and golobo3. This characteristic of bo3 makes it distinct from other Cantonese SFPs, some of which can only be used singly but not in particle clusters (e.g., aa5, le5), others can be used both singly and in particle-clusters (e.g., gaa3, laa3) but their primary uses are not in particle-clusters as is the case of bo3.

Earlier literature shows that bo3 could be used singly as well as in particle-clusters such as gaa3bo3, laa3bo3 and gaa3laa3bo3. In contrast to the very few examples found in the spoken data, quite a number of examples of bo3 used singly can be found in earlier literature. The decline in the single use of bo3 may be due to its replacement by wo 3 in the situations where $b o 3$ could once be used independently, that is to say, the two particles have merged as speakers chose to use the less effortful particle wo3, and consequently wo3 has gradually taken up the various functions of $b o 3$ and appears more frequently nowadays than bo3. However, bo3 has not become extinct; it still retains its importance in particle-clusters such as gaa3laa3bo3 and has not been totally replaced by wo3.

\section{Major findings and conclusions}

From the above examples and discussions, we see an imbalance of the frequency of use of the particles wo 3 and $b o 3$ in the language materials of the 1990s. The functions of the two particles mentioned in the previous sections can be illustrated as follows:

\begin{tabular}{lll} 
& \multicolumn{2}{c}{ Functions of wo3 and bo3 } \\
Stage & wo3 & bo3 \\
1990s & (1) Realization & (1) Contrast \\
& (2) Reminder & \\
& (3) Hearsay & \\
& (4) Contrast &
\end{tabular}

Performing four functions, the SFP wo3 in the late 20th century can be described as functionally versatile. It can also be used at the end of imperative and exclamatory sentences, a feature which cannot be found in past materials and thus believed to be a novel usage. In other words, the functions of wo3 seem to be expanding continuously.

As for the SFP bo3, the situation goes in the opposite direction. As we consult the past materials, the current finding almost excludes the usual tone of "emphasizing" which was commonly claimed by scholars in the early and middle of the 20th century (Ball 1888, 1924, O’Melia 1954, Cowles 1965). However, in contrast to the functionally versatile wo3, in the late 20th century its functions seemed to be contracting and there are no signs of its further development. From the examples of this particle in 3.1, the major use of the SFP bo3 is to show "contrast" in negative sentences. Moreover, it is remarkable that bo3 was rarely used singly in the late 20th century but tended to be generally used with gaa3, laa3, timl and zaal to form particle-clusters.

To sum up, the two SFPs carry and serve different meanings and functions in modern Hong Kong Cantonese, and thus they are not exactly the same particles and not interchangeable as previously assumed. Since recent scholars have tended to associate wo3 with bo3 (Kwok 1984, Ouyang 1990, Li 1995, Fang 2003) and the frequency of bo3 has greatly dropped over the past decades, it seems reasonable to figure out the relationships between the two particles diachronically to see how the particle wo3 has gradually developed in history and what functions it has performed by examining the diverse data in detail. Furthermore, the uses of the particle-clusters involving bo 3 in different periods of time are also worth studying in order to clearly show how bo3 has changed in the past one hundred years.

\section{References}

English

Ball, J. D. (1888). Cantonese Made Easy (2nd edition). HK: The China Mail Office.

Ball, J. D. (1924). Cantonese Made Easy (4th edition). HK: Kelly and Walsh Ltd.

Cowles, R. T. (1965). The Cantonese Speaker's Dictionary. The University of Hong Kong.

DeLancey, S. (1997). Mirativity: the grammatical marking of unexpected information. Linguistic Typology, 1-1, 33-52.

Kwok, H. (1984). Sentence Particles in Cantonese. Hong Kong: Centre of Asian Studies, University of Hong Kong.

Lau, S. (1975). Advanced Cantonese. Hong Kong: The Government Printer.

Leung, W. M. (2008). Promising Approaches for the Analysis of Sentence-final Particles in Cantonese. Asian Social Science, 5: 74-82. 
Leung, W. M. (2009). A Study of the Cantonese Hearsay Particle wo from a Tonal Perspective. International Journal of Linguistics, 1(1): 1-14.

Luke, K. K. (1990). Utterance Particles in Cantonese Conversation. Amsterdam; Benjamins.

Matthews, S. \& Yip, V. (1994). Cantonese: A Comprehensive Grammar. London and New York: Routledge.

Matthews, S. (1998). Evidentiality and mirativity in Cantonese: wo3, wo4, wo5!, Proceedings of the International Symposium on Chinese Languages and Linguistics, Academia Sinica.

O’Melia, T. A. (1954). First Year Cantonese. Hong Kong Catholic Truth Society.

Sung, H. P. (1934). Cantonese Conversation. Hong Kong.

Wisner, O. F. (1906). Beginning Cantonese. Canton: China Baptist Publ. Society.

Chinese

Cheung, H. N. 張洪年. (1972/2007). Cantonese as Spoken in Hong Kong《香港囷語語法的研究》. Hong Kong: Chinese University Press.

Deng, S. J. 鄧少君. (1991). “The Frequent Used Sentence-final Particles in Guangzhou Dialect”〈廣州方言常見的語 氣詞〉, Fangyan《方言》, 1991 no. 2.

Fang, X. Y. 方小燕. (2003). The Sentence-final Particles in Guangzhou Dialect《廣州方言句末語氣助詞》. Canton: Jinnan University Press.

Leung, C. S. 梁仲森. (2005). A Study of the Utterance Particles in Cantonese as Spoken in Hong Kong《當代香港粵語 語助詞的研究》. Hong Kong: City University Press.

Li, X. H. 李新鬼等. (1995). A Study of the Guangzhou Dialect《廣州方言研究》. Canton: Guangdong Renmin Chubanshe.

Ouyang, J. Y. 歐陽覺亞. (1990). “Sentence-final Particles in Cantonese”〈廣州話的語氣助詞〉, in Wang Li Memorial Volumes 《王力先生紀念論文集》. Beijing Commercial Press.

Rao, B. C. 饒秉才等. (1981). Cantonese Dictionary 《廣州話方言詞典》. Hong Kong Commercial Press.

Table 1. Scholars' views on the usage of bo3 and wo3 from 1888 to 2007

\begin{tabular}{|c|c|c|}
\hline Scholars & bo3 & wo3 \\
\hline Ball (1888) & $\begin{array}{l}\text { Very emphatic, used alone, or used with the final lo } \\
\text { (囉) or lok (咯). }\end{array}$ & $\begin{array}{l}\text { denoting that the statement } \\
\text { preceding it has been made by } \\
\text { some one before }\end{array}$ \\
\hline Wisner (1906) & $\begin{array}{l}\text { Imperative: the most decisive that can be used } \\
\text { Declarative: used in giving a decisive declaration } \\
\text { with reference to anything }\end{array}$ & No mention \\
\hline Ball (1924) & $\begin{array}{l}\text { Very emphatic, used alone, or often after the final lo } \\
\text { (囉) }\end{array}$ & $\begin{array}{l}\text { denoting that the statement } \\
\text { preceding it has been made by } \\
\text { some one before }\end{array}$ \\
\hline Sung (1934) & $\begin{array}{l}\text { Meaning you do not understand it yet, that deed is } \\
\text { really so. }\end{array}$ & No mention \\
\hline O’Melia (1954) & Emphatic declarative & No mention \\
\hline Cowles (1965) & A final: emphatic & No mention \\
\hline Cheung (1972) & Providing opinion, emphasizing & No mention \\
\hline Lau (1975) & Sign of an emphatic reminder or complaint & No mention \\
\hline Rao (1983) & Reminding, advising & No mention \\
\hline Kwok (1984) & $\begin{array}{l}\text { Remind the hearer to take something into special } \\
\text { consideration }\end{array}$ & Weakened form of bo3 \\
\hline Luke (1990) & Variant form of wo3 & $\begin{array}{l}\text { Unexpectedness, } \\
\text { noteworthiness, }\end{array}$ \\
\hline
\end{tabular}




\begin{tabular}{|c|c|c|}
\hline & & remarkableness, unusualness \\
\hline Ouyang (1990) & $\begin{array}{l}\text { Tones of negotiating, addressing criteria and request, } \\
\text { waiting for reply, orders and command. }\end{array}$ & $\begin{array}{l}\text { Reminding, discussing or } \\
\text { enlightening, same as bo3, but } \\
\text { lighter in tone. }\end{array}$ \\
\hline Deng (1991) & $\begin{array}{l}\text { Feeling of the speaker, negotiating with others, } \\
\text { reminding, urging. }\end{array}$ & No mention \\
\hline Leung (1992) & $\begin{array}{l}\text { Lack of self-opinion, asking for advice and } \\
\text { agreement, begging for reminders, milder than wo3 in } \\
\text { tone. }\end{array}$ & $\begin{array}{l}\text { The meaning of having the } \\
\text { responsibility, duty to do so, } \\
\text { discussing, ordering, new } \\
\text { message. }\end{array}$ \\
\hline $\begin{array}{l}\text { Matthews \& Yip } \\
\text { (1994) }\end{array}$ & Exclamatory, appreciative & Informative (noteworthiness) \\
\hline Li (1995) & $\begin{array}{l}\text { Emphasizing, to draw the hearer's attention to what } \\
\text { may be neglected, or the speakers suddenly notice a } \\
\text { situation. }\end{array}$ & Weakened form of $b o 3$. \\
\hline Fang (2003) & $\begin{array}{l}\text { Reminding, emphasizing, exclaiming, blaming and } \\
\text { enlightening and accusing. }\end{array}$ & Weakened form of $b o 3$. \\
\hline Cheung (2007) & Providing opinion, emphasizing & No mention \\
\hline
\end{tabular}

\section{List of abbreviations}

$\begin{array}{ll}\text { ADV } & \text { Adverb } \\ \text { ASP } & \text { Aspect } \\ \text { AUX } & \text { Auxiliray } \\ \text { CL } & \text { Classifier } \\ \text { COMP } & \text { Complement marker } \\ \text { COP } & \text { Copular } \\ \text { DEM } & \text { Determiner } \\ \text { DM } & \text { Discourse marker } \\ \text { GEN } & \text { Genitive } \\ \text { INJ } & \text { Interjection } \\ \text { NEG } & \text { Negator } \\ \text { PL } & \text { Plural } \\ \text { PRE } & \text { Prefix } \\ \text { SFP } & \text { Sentence-final Particle } \\ \text { SG } & \text { Singler }\end{array}$

